\title{
Mapping future changes in livelihood security and environmental sustainability based on perceptions of small farmers in the Brazilian Amazon
}

\author{
$\underline{\text { Fabio H. Diniz }}{ }^{1}, \underline{\text { Kasper Kok }}^{2}$, Marjanke A. Hoogstra-Klein $^{3}$ and Bas Arts $^{4}$
}

\begin{abstract}
Deforestation is a widely recognized problem in the Brazilian Amazon. Small farmers play a key role in this process in that they earn their livelihood by ranching and farming. Many studies have addressed the link between deforestation and livelihood strategies adopted by small farmers. Most have focused on advanced monitoring systems, simulation models, and GIS approaches to analyze the interaction of both dimensions, i.e., livelihoods and forest cover change. Although the current toolbox of methods has proved successful in increasing our understanding of these interactions, the models and approaches employed do not consider small farmers' perspectives. On the assumption that local small farmers are agents of land-cover change, understanding how they perceive their own situation is essential to elucidate their actions. Our objective is to explore future changes in livelihood security and environmental sustainability as envisaged by local small farmers in the Brazilian Amazon. Previous livelihood cluster analysis of small farmers located in southeast Pará was integrated with fuzzy cognitive mapping to determine present perceptions and to explore future changes, using global scenarios downscaled to the local situation. Overall, system description differs only on details; all results indicate a strong trade-off between livelihood security and environmental sustainability in all livelihood systems, as identified by the small farmers. However, fundamentally different outcomes are obtained from the future analysis, depending on the livelihood strategy cluster. Achieving win-win outcomes does not necessarily imply a positive scenario, especially if small farmers are dependent on income transfers from the government to provide their livelihood.
\end{abstract}

Key Words: Brazil; deforestation; fuzzy cognitive maps; mental model; Pará; scenarios

\section{INTRODUCTION}

Deforestation in the Brazilian Amazon region is a widely recognized problem, with multiple local, regional, and global negative consequences, e.g. biodiversity loss, soil degradation, and climate change (Shukla et al. 1990, de Miranda and Mattos 1992, Hecht 1993, Moran 1993, Faminow 1997, Fearnside 2005, Scouvart et al. 2008). In 2012, the cumulative deforested area amounted to approximately $750,000 \mathrm{~km}^{2}$, or $18.7 \%$ of the forested area of the entire region (INPE/PRODES 2012). Although a substantial slowdown in deforestation from about $27,000 \mathrm{~km}^{2}$ to less than $5000 \mathrm{~km}^{2}$ per year has been recorded over the past 10 years, the Brazilian Amazon forest remains under threat caused mainly by ranching and farming (Caviglia-Harris 2004, Betts et al. 2008, INPE/PRODES 2012). These activities represent about $67 \%$ of the deforested area, divided between pasture $(62 \%)$ and annual agriculture (5\%; EMBRAPA and INPE 2011).

Most of the deforestation has been attributed to large ranchers and large soybean producers (Hecht 1989, Rosa et al. 2012, Godar et al. 2012). Nevertheless, small farmers also have been named as agents of deforestation because the use of agricultural land is fundamental to them to provide their livelihoods (Fujisaka et al. 1996, Marquette 1998, Vosti et al. 2003, Salisbury and Schmink 2007). It is thus important to study and understand livelihood strategies. However, livelihoods are influenced by many factors on different scales and levels, such as contextual factors and various types of capital (human, social, economic, physical, and natural), mediated by a large number of structures and processes, such as rules, policies, organizations, and state agencies (Chambers and Conway 1991, Scoones 1998, Ellis 2000). Livelihood security and environmental sustainability are affected by the combination of all of these factors over time. Livelihood security can be understood as people obtaining and maintaining access to essential resources to ensure their immediate and longterm survival, improving their livelihood condition over time (Chambers and Conway 1991). In turn, environmental sustainability in the Amazonian situation can be indicated by forest cover at property level; forest conservation implies better environmental sustainability in terms of biodiversity, soil conservation, and water availability (Scoones 1998). Thus, the trade-offs between livelihood security and environmental sustainability are a day-to-day reality, with possible implications for the future of the Amazonian rainforest (Kirby et al. 2006, Hecht 2012).

Many studies have addressed the interplay between deforestation, livelihood strategies, agricultural activities, and other direct and indirect drivers (Line Carpentier et al. 2000, Moran et al. 2003, Muchagata and Brown 2003, Vosti et al. 2003, Brondízio 2005, Salisbury and Schmink 2007, Pacheco 2009). Studies of such human-environment interactions in the Brazilian Amazon have used manifold approaches, such as advanced monitoring systems, simulation models, and GIS, to describe the relationships between deforestation and its drivers in time and space, be they biophysical, infrastructural, or demographic (Laurance et al. 2001, McCracken et al. 2002, Kirby et al. 2006, Soares-Filho et al. 2006,

${ }^{1}$ Brazilian Agricultural Research Corporation, Embrapa Dairy Cattle, Brazil, ${ }^{2}$ Soil Geography and Landscape Group, Department of Environmental Sciences, Wageningen University, The Netherlands, ${ }^{3}$ Forest and Nature Conservation Policy Group, Department of Environmental Sciences, Wageningen University, The Netherlands, ${ }^{4}$ Forest and Nature Conservation Policy, Department of Environmental Sciences, Wageningen University, The Netherlands 
Malhi et al. 2008). The growing understanding of the relationships between deforestation and the complex web of drivers is essential to support effective policy and decision-making processes, contributing toward a more balanced interaction between forest cover and local people's livelihoods. Although the current toolbox of methods has proved successful in increasing the understanding of these relationships, methods that attempt to analyze human-environment interactions from the reality perceived by local stakeholders have been scarce in Amazonian studies (Posey 1996, Muchagata and Brown 2000, Humphries and Kainer 2006, Soler et al. 2012). However, understanding how stakeholders perceive their own situation could be essential in understanding their actions. Therefore, they can, and perhaps should, be enabled to conduct their own analysis of their own reality (Chambers 1994, Lynam et al. 2012). Moreover, recognizing and dealing with the pluralities of stakeholders' perceptions is currently considered a key aspect of effective natural resource management for the sustainability of humanenvironment systems (Rajaram and Das 2010, Jones et al. 2011). On the assumption that local stakeholders are in many cases agents of landscape changes, their practice-based knowledge about reality is crucial in better understanding future changes in human-environment interactions, i.e., livelihoods security and environmental sustainability (Moore 1979, Schiere et al. 2004, Fearnside 2008).

Recently, mental model studies have emerged as an alternative approach to better understand stakeholders' constructions of how a system functions and what factors might be brought to bear on actual practices (Du Toit et al. 2011, Papageorgiou 2011). A mental model refers to a simplified cognitive representation of reality, allowing people to interact with the world on the basis of their perceptions (Jones et al. 2011). Using factors and relationships between factors that underpin how people understand, filter, and process information about their realities, this approach seeks to elicit and analyze individual and group cognitive structures (Craik 1967, Biggs et al. 2011, Du Toit et al. 2011, Jones et al. 2011). Moreover, mental models have the capacity to represent dynamic causes and effects of a phenomenon, enabling people to describe, explain, and explore changes in the system (Jones et al. 2011). We focus on the exploration of future changes in human-environment interactions, extrapolating from the current practical knowledge about livelihoods and forest-cover change of the local stakeholders, i.e., small farmers, using tools and techniques to capture the cognitive representation (mental models) that these stakeholders have of their reality.

A range of tools and techniques, such as consensus analysis and the actors, resources, dynamics, and interactions (ARDI) process, have been recommended as elicitation approaches to better capture and measure mental models in human-environmental interactions (Stone-Jovicich et al. 2011, Cheong et al. 2012, Lynam et al. 2012). Consensus analysis is designed to elicit fundamental knowledge structures among a given group of people, based on systematic individual interviews (Jones et al. 2011, Stone-Jovicich et al. 2011, Lynam et al. 2012). However, this method has limitations when used to explore complex domains with a high diversity of issues, such as we address in this paper (Stone-Jovicich et al. 2011). In turn, the application of the ARDI process provides an analytical perspective toward understanding the elements shared among people, but it does not provide a shared mental model (Lynam et al. 2012).

Other semiquantitative tools, such as fuzzy sets and fuzzy cognitive mapping, have been used to capture the internal representation (mental model) of external realities of stakeholders, taking account of their perception of causes and effects in human-environment interactions (Özesmi and Özesmi 2004, Jones et al. 2011, Cheong et al. 2012). In fuzzy cognitive mapping, the local stakeholders build models that represent human-environment interaction, specifying factors and the causes and effect relationships between factors according to their practical knowledge about the system (Özesmi and Özesmi 2004, Jones et al. 2011). The tool captures a mental model that is not limited by exact values and measurements, and thus it is well suited to represent relatively unstructured knowledge and causalities expressed in imprecise forms (Isak 2008). By involving causeeffect relations and feedback mechanisms (Kosko 1986), fuzzy cognitive mapping can be used to uncover present realities that can be used to evaluate the effect of future livelihood and forest cover changes. In this context, it has been used as a semiquantitative tool to indicate future changes, taking account of stakeholders' current perceptions and existing scenarios (Kok 2009, Soler et al. 2012). Moreover, lately studies have indicated it as a potential tool to capture the complex dynamics of deforestation (Kok 2009, Soler et al. 2012, Wulms 2012) and also to analyze the functioning of different livelihoods and the vulnerability of these livelihoods to external changes (Murungweni et al. 2011). Thus, fuzzy cognitive mapping is appropriate to capture mental models of the complex systems addressed in this paper, i.e., livelihoods and the environment in (de)forested landscapes. Moreover, capturing current mental models of complex systems can contribute toward exploring the potential impact of future changes. Such insight can help to give direction to possible measures that need to be taken today. This is more difficult to reach by studying current systems only. It is in this regard that fuzzy cognitive mapping is particularly powerful.

By considering present and future perspectives in humanenvironmental interactions, this paper seeks to contribute toward a systemic approach that can be used to structurally analyze tradeoffs between two, often conflicting, goals, as presented previously: to enhance the livelihood security of local small farmers and to decrease the rate of deforestation. Therefore, the objective of this study is to use local small farmers' current perceptions of their realities to explore plausible future changes in livelihood security and environmental sustainability in the Brazilian Amazon. With fuzzy cognitive mapping as a tool, the specific objectives are as follows: (1) to identify local small farmers' current perceptions of the factors affecting their livelihoods and the forest; (2) to analyze possible differences in perceptions dictated by their adopted livelihood strategies; (3) to explore plausible future changes in livelihoods and forests.

\section{Principles of fuzzy cognitive mapping}

A fuzzy cognitive map (FCM) is a graphical interpretation of a system represented by cause-effect relationships among factors concerning a particular domain at a point in time (LangfieldSmith and Wirth 1992, Groumpos 2010). When developed using participatory methods, it provides a structured overview of the individual or group perception of reality. An FCM consists of 
factors joined by weighted arrows. The factors represent the key elements influencing the system; the arrows represent the causal relationships that exist among them (Kok 2009). Relative weights are used to quantify strengths of causal relationships between the factors (Kosko 1986). The weights of the interconnections can vary in the interval $[-1,1]$, where the maximum and minimum values indicate a complete causal interrelationship among factors (Groumpos 2010). All weights attributed to the relationships can be represented as a matrix; initial values of the factors can be represented by a vector indicating the relative change of all factors, which is initially set at zero (see Kok 2009 for a detailed explanation). Subsequently, a change can be introduced to the system by assigning a nonzero value to one (or more) of the factors. This value indicates the strength of the change introduced. For example, setting the value of a box "Environmental Policies" at 0.5 indicates an increase in the influence of those policies that is half as strong as it maximally could be. This change will affect the state of all other factors to which it is related, directly or indirectly, as the effect ripples through the system. Eventually, all factors will have a (stable) new value. Mathematically, this process can be simulated by a simple matrix multiplication (e.g., in Microsoft Office Excel ${ }^{\circledR}$ ), which yields a new change vector. This multiplication can then be repeated with the new change vector. This iterative procedure provides a dynamic output of changing values of the factors. The word "dynamic" is used, although strictly speaking the rippling effect is evaluated as an introduced change, which mathematically is more correctly described as quasi-dynamic, which can lead to a quasi-stabilization of the system. Importantly, this implies that, in the dynamic output, the number of iterations cannot be replaced by time (Kafetzis et al. 2010). In turn, this allows an interpretation of the dynamics of the different factors relative to the other factors, or relative to other system descriptions (Kafetzis et al. 2010, Wulms 2012).

To better illustrate how an FCM works, an example of an FCM applied to land-use changes is shown in Figure 1 (Soler et al. 2012). This figure represents a simple system, where F2 and F3, e.g., number of national parks, or environmental policy, influence the amount of forest (F1). In turn, the amount of forest strongly influences F3. In this simple system, this negative feedback loop between F1 and F3 stabilizes the amount of forest in the area. Table 1 shows the matrix of all possible relationships between all factors. By giving F2 a value of, e.g., 1, the value of F1 becomes 0.6 after one iteration and the value of $\mathrm{F} 3$ becomes 0.6 after two iterations, which in turn will decrease the value of $F 1$, until stable values are obtained for all factors.

Fig. 1. Graphical representation of a simple fuzzy cognitive map, indicating the factors (F1, F2, and F3), the causal relationship, and weights between factors. Based on Soler et al. 2012.

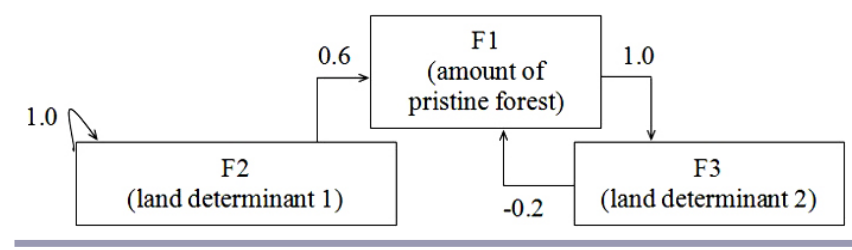

Table 1. Tabular representation of all possible relationships between the three factors shown in Figure 1 for the initial iteration.

\begin{tabular}{lccc}
\hline \hline & $\begin{array}{c}\text { F1: Amount } \\
\text { of } \\
\text { pristine forest }\end{array}$ & $\begin{array}{c}\text { F2: Land } \\
\text { determinant 1 }\end{array}$ & $\begin{array}{c}\text { F3: Land } \\
\text { determinant 2 }\end{array}$ \\
\hline $\begin{array}{l}\text { F1: Amount of } \\
\text { pristine forest }\end{array}$ & 0 & 0 & 1.0 \\
$\begin{array}{l}\text { F2: Land } \\
\text { determinant } 1\end{array}$ & 0.6 & 1.0 & 0 \\
$\begin{array}{l}\text { F3: Land } \\
\text { determinant 2 }\end{array}$ & -0.2 & 0 & 0
\end{tabular}

The absence of an arrow is represented by a zero in the table.

FCMs can represent a group's shared perceptions about a particular domain in a particular time (Langfield-Smith and Wirth 1992, van Vliet et al. 2010). They are helpful in understanding common or diverging priorities and perceptions of the same social group, but also subgroups, in this case, small farmers with different livelihood strategies. Others have shown that the process of developing participatory FCMs is intensive and sometimes difficult for involved stakeholders (van Vliet et al. 2010). However, the same studies report how using the tool can lead to a process that generates a deeper understanding of the factors that affect the system under study, for scientists, policymakers, and other stakeholders alike. Here, we present a case study in Brazil, where we focus on the interactions between livelihood security and environmental sustainability in (de) forested landscapes.

\section{METHODS}

\section{Case study}

The case study is located in southeastern Pará State, in the municipality of Eldorado do Carajás (Fig. 2). Covering about $3000 \mathrm{~km}^{2}$, the municipality has undergone an intensive process of deforestation in the past decades (Diniz et al. 2013a). From 1985 to 2010 , forest cover shrank from about $85 \%$ to roughly $10 \%$ of the municipality's total area (INPE/PRODES 2012). In 2008, pasture areas covered approximately $2100 \mathrm{~km}^{2}$ or $78 \%$ of the deforested areas in Eldorado do Carajás (EMBRAPA and INPE 2011). The main agricultural activity in the municipality is cattle ranching, mainly milk production on small farms. About $67 \%$ of the municipal area is used by roughly 4600 small farmers in 21 settlement projects under the Agrarian Reform Program (ARP). The ARP beneficiaries (called settlers or small farmers interchangeably in this paper) are landless rural workers and small squatters/colonists. The ARP aims to help poverty alleviation and to promote socioeconomic development by redistributing large public areas and extensive areas held by private landholders to landless people so that settlers can earn their living by small-scale commercial farming, producing an agricultural surplus for the market (Fearnside 2001, MDA/INCRA 2004). Consequently, agricultural land availability is fundamental to the settlers to provide their livelihoods; this is causing huge pressure on the forest. However, settlers also have to fulfil the requirements of the environmental law (Federal Law 12.727/2012 - Brazilian Forestry Code), which implies keeping $80 \%$ of the area of their properties covered by forest. 
Fig. 2. Case study municipality and selected settlement projects. Source: INPE 2011, INCRA 2012.

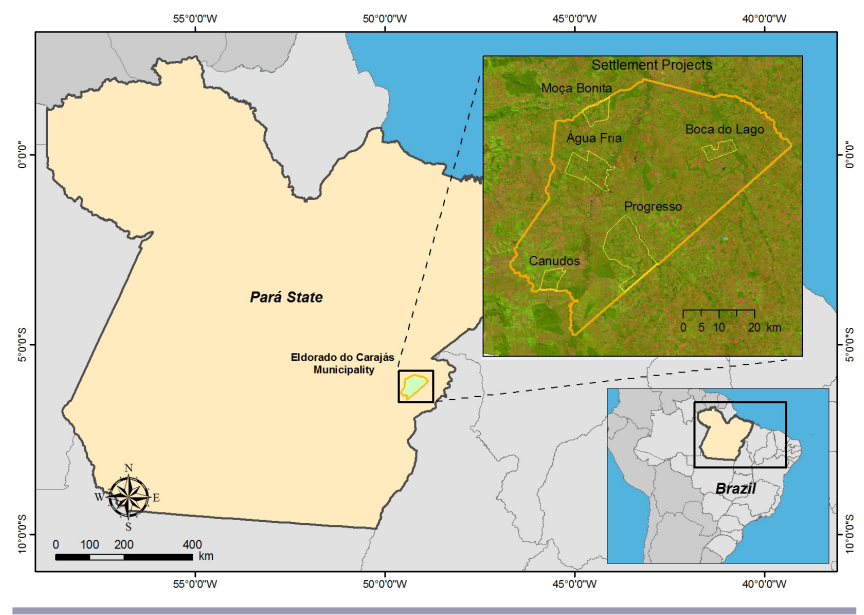

\section{Characterization of the livelihood strategies of the local small farmers}

We build on a combination of quantitative (factor and cluster analysis) and qualitative methods (content analysis, open-ended recorded interviews) used to cluster 42 households in the same study area, by livelihood strategy (Diniz et al. 2013b). Carried out in 2010, the study identified three different livelihood strategies: livestock-, diversified-, and off-farm-oriented small farmers. These livelihood strategy clusters are considered subgroups of small farmers who share views about the factors relating to their livelihood security.

Livestock-oriented small farmers (16 households) base their livelihood on extensive livestock farming. The main source of income is milk production, with crop areas, of cassava, rice, corn, and beans, cultivated for home consumption. A livestock background has driven most of these settlers into this cluster, reinforced by an accessible market (milk and beef) and available credit for cattle breeding.

Diversified-oriented small farmers (13 households) are characterized by a more diverse set of land uses and means to generate income. Small farmers in this cluster have a significantly larger crop area than those in the other two clusters. Crop income is mostly based on the cassava flour and rice markets. Off-farm income, such as pensions and subsidies (bolsa família, family allowance) are also significant for this group. The accessible market (milk and beef) and available credit for cattle breeding have also driven the diversification observed in this cluster.

Off-farm-oriented small farmers (13 households) have the most off-farm sources of income for their livelihood. The majority of income comes from labor on other farms, ownership of small shops, and labor in external organizations. Government transfers such as pensions and family allowances also play an essential role in this livelihood cluster.

\section{Constructing the fuzzy cognitive maps}

To obtain the FCMs, three workshops were conducted in Eldorado do Carajás in 2011 with the small farmers from the three livelihood strategy clusters separately. Not all small farmers from the three clusters participated in the workshop, even though they were all invited. Other commitments prevented the participation of all. Ultimately, the number of participants in each workshop was as follows: 11 from the livestock, 8 from the diversified, and 7 from the off-farm cluster. On average, each workshop took 3 hours.

The workshops started with an explanation of the meaning of FCM. It was explained to the participants that the aim of each workshop was to construct a cognitive map with factors affecting, positively or negatively and directly or indirectly, livelihood security and environmental sustainability in their perception. After that, to speed up and systematize the process, we suggested general level factors that took into account many cause-effect factors that potentially affect livelihood security and environmental sustainability (Table 2). These general factors were obtained from previous individual open-ended interviews with the same workshop participants. In the workshop, the participants were free to suggest other factors or general factors to be included in, or excluded from, the FCM. All factors and general factors considered in the analysis were agreed by consensus among the participants.

Together with the relationships made between factors, the quantitative weights of these relationships were also provided. To facilitate the discussion on the exact weights, we initially offered the participants four categorical weights, i.e., very strong, strong, weak, or very weak. These categories were associated with numerical weights $(+/-1.00,+/-0.75,+/-0.50$ and $+/-0.25)$. However, the participants in all three workshops quickly started to refer to the numerical weights. The outputs of the workshops were three "raw" fuzzy cognitive maps, one for each livelihood strategy, representing the participants' current perceptions of the factors affecting their livelihood security and environmental sustainability (Figure 3).

Fig. 3. Example of a fuzzy cognitive map obtained in the offfarm workshop.

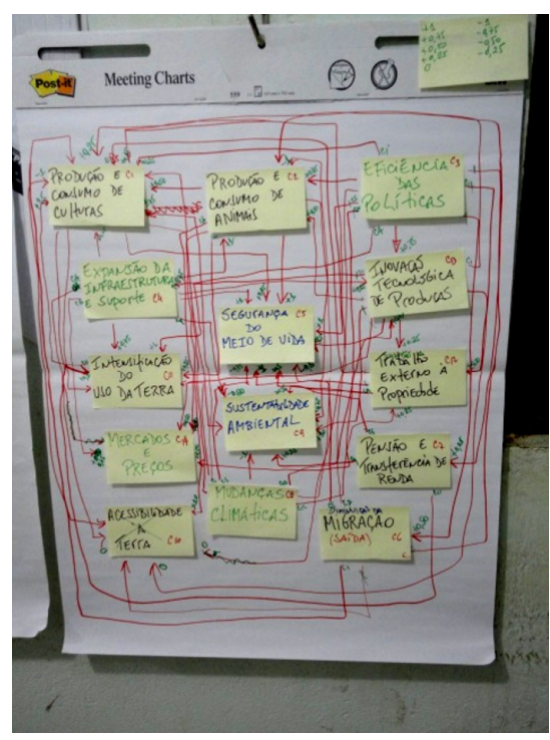


Table 2. General factors and related factors agreed on in the workshops.

\section{No. Factors \\ F1 Crop production and consumption: This group of factors represents all kinds of crops cultivated within the property for sale or home consumption, mostly cassava, rice, corn, beans, fruits, etc. \\ F2 Livestock production and consumption - this group of factors represents all kinds of livestock breeding within the property for sale or home consumption. Livestock are mostly dual-purpose cattle (milk and beef) and small livestock such as goats, chickens, and pigs. \\ F3 Technological innovation of production: This group of factors includes all technological innovation available to increase livestock and crops yields, such as artificial insemination, cultivation of fodder crops (e.g., sugar cane), cooler bulk tanks to store milk, etc. \\ F4 Policy effectiveness: This group of factors relates to agrarian policies (credit, technological assistance, improvement of infrastructures) and environmental policies (Forestry Code requirements) and the extent to which they achieve their ends. \\ F5 Intensification of land use: This group encompasses the intensification of current crops and livestock, increasing productivity (higher yields in smaller areas).}

F6 Livelihood security: This means that people obtain and maintain access to essential resources to ensure their immediate and long-term survival, improving their livelihood condition over time.

F7 Infrastructure and support expansions: This group of factors encompasses infrastructural improvements at local level, such as new roads, bridges, electricity, drinking water, hospitals, schools, and social organizations at settlement project level.

F8 Markets and prices: This group of factors includes market access in terms of the existence of the market and of physical accessibility (roads). This item also includes the price of products and its variation over the year (e.g., milk price variation in the rainy and dry seasons).

F9 Environmental sustainability: This group is basically indicated by forest cover at property level (forest conservation implies better environmental sustainability in terms of biodiversity, soil conservation, and water availability).

F- Reduction of off-farm labor: This item indicates whether people are

10 making their living from on-farm activities or whether they depend on off-farm labor for livelihood security.

F- Migration: This item refers to the necessity for people to leave their

11 properties to go to other regions for a couple of months to make their living.

F- Intensification of drought: This item means the increase in dry

12 periods per year (the current dry season is from May to September).

F- Pensions and subsidies: This group encompasses social welfare

13 programs from the government such as pensions (on retirement or in the event of illness) and subsidies (bolsa familia, a specific program of cash transfer for poor people with children).

The target factors (livelihood security and environmental sustainability) are in bold.

\section{Postprocessing the fuzzy cognitive maps}

The FCMs were postprocessed in three steps. First, all factors and their respective relationships from each map obtained in the workshops were listed. After that, the weights of the relationships were slightly changed. The main reason for this was that the initial dynamic results proved to be very instable. As indicated in Table 3 , it was decided to change the values of the classes used. In particular, the "very strong" and "very weak" relationships were weakened. This had a stabilizing effect on the dynamic output without fundamentally changing the values provided by the workshop participants.
Table 3. Redesigned table of categorical and numerical weights.

\begin{tabular}{lc}
\hline \hline Categorical change & Numerical change \\
\hline Very strong & $+/-0.90$ \\
Strong & $+/-0.70$ \\
Weak & $+/-0.40$ \\
Very weak & $+/-0.10$ \\
Related factors, but not weighted & 0.00 \\
\hline
\end{tabular}

Then, tables were made listing the relationships and the respective weights (Table 4). These tables were used to execute a detailed content analysis of the causal relationships between factors present in the maps, discarding redundancy; including missing arrows; and changing values of weights. Redundancy occurred when the same relationship was represented twice, removing arrows that describe the same interactions. For instance, the participants in the livestock workshop connected technological innovation (F3) directly to livelihood security (F6). At the same time, $\mathrm{F} 3$ relates to crop production $(\mathrm{F} 1)$, which in turn relates to F6. In this way, the process of technological innovation that leads to increasing crop production, which leads to increased livelihood security, is included twice. The direct relationship from F3 to F6 was therefore removed. Missing arrows are those that were not included, even though relations were mentioned during discussions.

Table 4. Example of the relationships and weights from the livestock workshop.

\begin{tabular}{|c|c|c|c|c|c|c|}
\hline \multicolumn{2}{|c|}{ From } & \multicolumn{2}{|l|}{ To } & \multirow{2}{*}{$\begin{array}{c}\text { Sig- } \\
\text { nal } \\
\\
+\end{array}$} & \multirow{2}{*}{$\begin{array}{c}\text { Check } \\
\text { and } \\
\text { update } \\
\text { weight } \\
0.90\end{array}$} & \multirow{2}{*}{$\begin{array}{c}\begin{array}{c}\text { Calibration: } \\
\text { assigning } \\
\text { values }\end{array} \\
0.70\end{array}$} \\
\hline F3 & $\begin{array}{l}\text { Technological } \\
\text { innovation of } \\
\text { production }\end{array}$ & $\mathrm{F} 1$ & $\begin{array}{l}\text { Crop production } \\
\text { and consumption } \\
\text { (cassava, rice, corn, } \\
\text { beans, fruits, etc.) }\end{array}$ & & & \\
\hline F3 & $\begin{array}{l}\text { Technological } \\
\text { innovation of } \\
\text { production }\end{array}$ & $\mathrm{F} 2$ & $\begin{array}{l}\text { Livestock } \\
\text { production and } \\
\text { consumption, } \\
\text { involving milk, } \\
\text { beef, and small } \\
\text { livestock (e.g., } \\
\text { goats, pigs, and } \\
\text { chickens) }\end{array}$ & + & 0.90 & 0.90 \\
\hline F3 & $\begin{array}{l}\text { Technological } \\
\text { innovation of } \\
\text { production }\end{array}$ & F6 & Livelihood security & + & Out & Out \\
\hline F3 & $\begin{array}{l}\text { Technological } \\
\text { innovation of } \\
\text { production }\end{array}$ & F9 & $\begin{array}{l}\text { Environmental } \\
\text { sustainability }\end{array}$ & + & Out & Out \\
\hline
\end{tabular}

The second step was to calibrate the weights in the relationships by assigning values. The calibration consisted of stabilizing the change vector by varying the strength of the additional feedback, assuming that the systems were in or near equilibrium (see Kok 2009). In this step, some values were slightly changed with the aim of getting a stabilized graph at the end of the interactions (see Table 4). 
After the FCMs were calibrated, a sensitivity analysis was performed. This third step served a double purpose. On the one hand, it provided insights into the behavior of the system and the relative importance of the various factors. On the other hand, knowledge on relative importance was crucial for determining factors that were to be changed in the next analysis. The sensitivity analysis was performed by systematically changing the values of the change vector for each factor (Kok 2009). After these three steps, the resulting maps and matrixes from the three FCMs, based on small farmers' perceptions broken down by livelihood strategy cluster, were compared, identifying main similarities and differences among them.

When two or more FCMs are compared, three types of differences can be identified: (1) existence or nonexistence of factors: one FCM regards certain aspects within a domain as important, whereas the other FCM does not; (2) representation of different belief systems in a given domain: one group holds certain beliefs that the other group does not hold; (3) identical factors held with differing strengths: two FCMs have the same factors, but one FCM deems the interaction between factors to be stronger than the other FCM does (Langfield-Smith and Wirth 1992). These types of difference were used to compare the three FCMs obtained in this study.

\section{Exploring future changes using the fuzzy cognitive maps}

We used the three livelihood strategy-specific and postprocessed FCMs to explore future changes under plausible future scenarios. Future scenarios are understood here as a set of changes to the context of the system as captured by the FCMs. The intention, therefore, is to evaluate the effect of these sets of changes on the dynamics of the system. Instead of developing plausible future scenarios from scratch, we decided to build on the most recent set of global scenarios available, the shared socioeconomic pathways (SSPs) that are currently being drafted for inclusion in the next assessment report of the IPCC (IPCC 2012, O'Neill et al. 2012; Kok and Laurence, unpublished manuscript). SSPs focus on mitigation and adaptation processes relating to people, livelihoods, infrastructure, ecosystems, services, and resources among other dimensions that could be adversely affected by climate change (IPCC 2012). One of the key characteristics assumed by the SSPs is that a narrative of future global development elaborated under global assumptions should also be relevant for local and regional scale scenarios (IPCC 2012).

From the key characteristics, Kok and Laurence (unpublished manuscript) downscaled to Latin America the driving factors from the global SSPs of alternative developments. Among the five scenarios developed in terms of socioeconomic challenges for mitigation and adaptation, two exploratory scenarios were chosen for this study, i.e., SSP1: sustainability, and SSP3: fragmentation (Kok and Laurence, unpublished manuscript). They were chosen to reflect the small farmers' current expectation as captured in the FCMs, with two extremes: an optimistic and a pessimistic scenario, respectively.

Focusing on mitigation and adaptation potential, SSP1 represents an optimistic scenario toward sustainability where rapid technological innovation toward crop and livestock production will reduce the demand for land, improve degraded grasslands, increase yields, and improve drought resistance. In this scenario, policies are effective, providing infrastructure for the settlers, timely credit access, and adequate technological assistance. Secondary forest is expanding because of land use intensification and the effectiveness of monitoring and enforcement systems by national institutions such as the National Institute for Space Research (INPE) and the Brazilian Institute of Environment and Renewable Natural Resources (IBAMA), respectively, reaching the parameters of forest cover indicated in the Forestry Code. In this scenario, positive and negative values ( 1 for policy effectiveness and -1 for intensification of drought) are attributed to the change vector of these sensitive factors in each FCM matrix, and a positive value (1) is attributed to an external factor. This external factor is considered as a set of factors that can cause disturbance in the equilibrium of the system, affecting its resilience (Kok 2009). As an example, in our study this external factor includes a radical political change or natural disasters.

SSP3, in turn, is a pessimistic scenario looking toward a fragmented situation where settlers are not able to access technological innovation because of the weakness of policies and institutions. Low investments in human capital cause more deforestation and soil degradation. Drought becomes intensive, and settlers do not have options to earn their livelihood on their properties from agricultural activities, provoking a massive migration to the cities or to other unplanned settlements established in new Amazon frontier areas, causing more deforestation. In this alternative development, positive and negative values ( 1 for intensification of drought and -1 for policy effectiveness) are attributed to the change vector of these sensitive factors in each FCM matrix, and a negative value (-1) is attributed to an external factor as well.

\section{RESULTS}

\section{Small farmers' current perceptions among livelihood strategy} clusters: similarities and differences

Figures 4, 5, and 6 present the postprocessed FCMs from the three workshops, by livelihood cluster. These FCMs express, therefore, the current perception of the participants about their reality, as reconstructed in the three workshops. These maps indicate that the participants agree with the general factors suggested in Table 2. There is just one exception: the participants in the livestock workshop consider factor F10 (reduction of off-farm labor) not relevant to them, so there are no arrows to or from that factor in their FCM.

Table 5 shows the key characteristics of the resulting maps. By and large, there are strong similarities, with similar values for number of relationships, number of factors, and density. As already stated, the workshop participants from the livestock cluster did not consider factor F10 (reduction of off-farm labor) important for them. The number of relationships in the diversified cluster is higher than in the others, indicating that small farmers within this cluster have a broader view of their system because they are involved in more activities, dealing with a higher number of institutions, such as government offices and markets. This cluster also presents more negative relationships than the others, but the number of receiving and transmitting relationships is similar to the other clusters. One factor (F11 migration) was not considered as a causal factor in any of the three FCMs. Reduction of migration is considered an effect of other factors in all livelihood clusters. 
Fig. 4. Postprocessed fuzzy cognitive map resulting from the livestock workshop. Grey boxes are the target factors of the analysis, white boxes are the general factors, and white circles are the drivers of the system. Numbers given are the weights between factors, indicating positive and negative relationships. The crossed out box indicates the factor excluded by the participants.

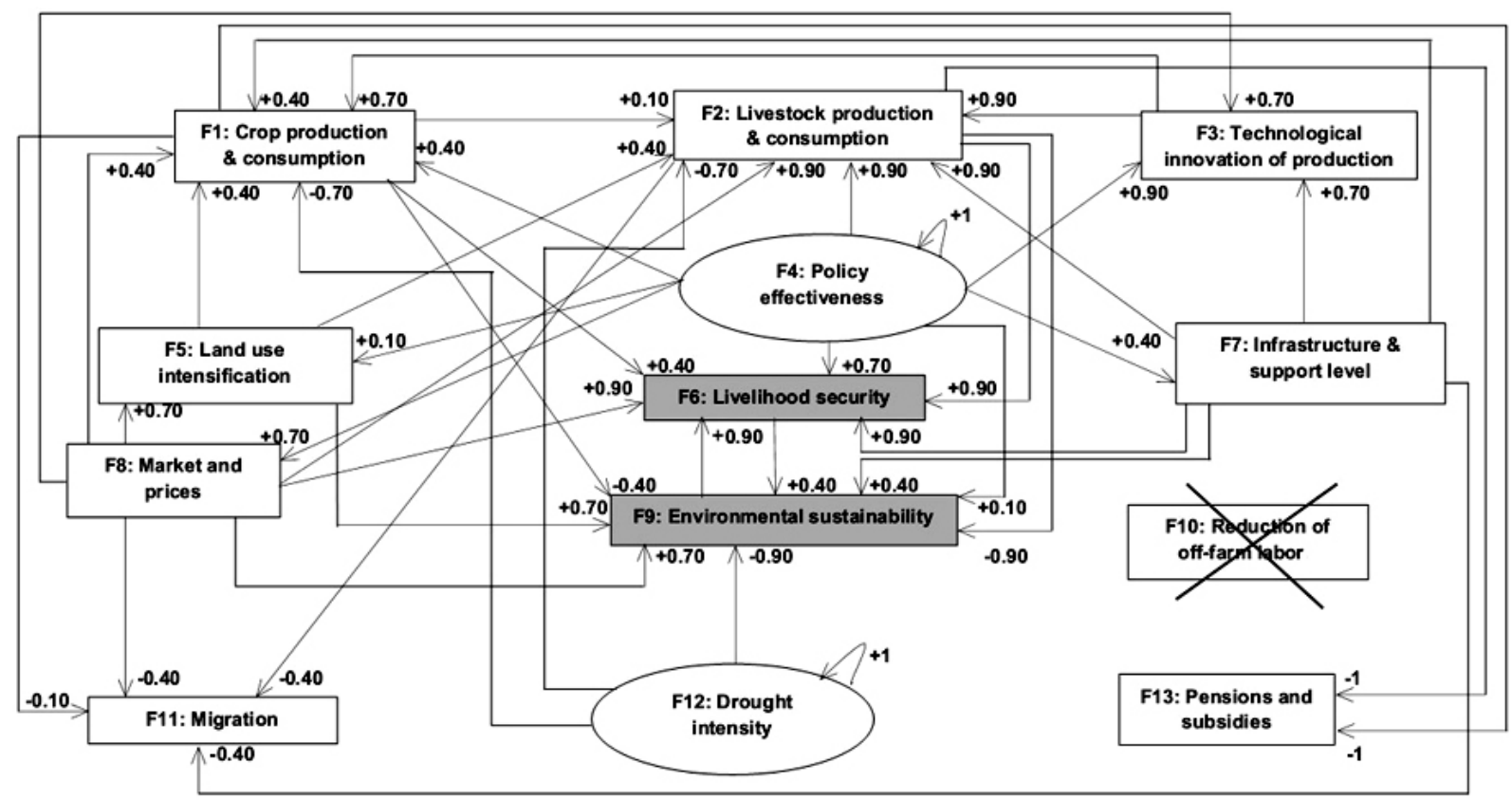

Fig. 5. Postprocessed fuzzy cognitive map resulting from the diversified workshop. Grey boxes are the target factors of the analysis, white boxes are the general factors, and white circles are the drivers of the system. Numbers given are the weights between factors, indicating positive and negative relationships.

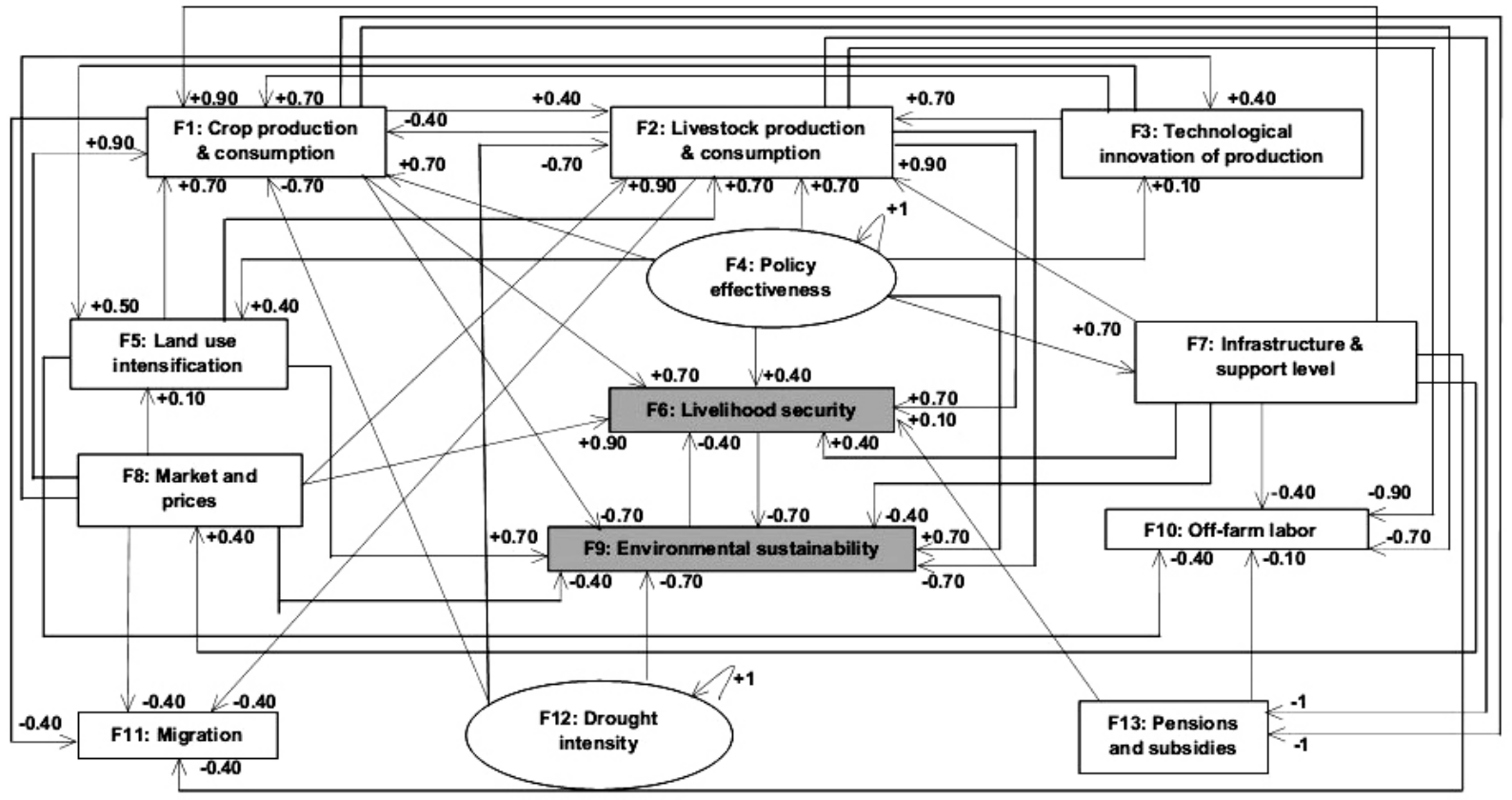


Fig. 6. Postprocessed fuzzy cognitive map resulting from the off-farm workshop. Grey boxes are the target factors of the analysis, white boxes are the general factors, and white circles are the drivers of the system. Numbers given are the weights between factors, indicating positive and negative relationships.

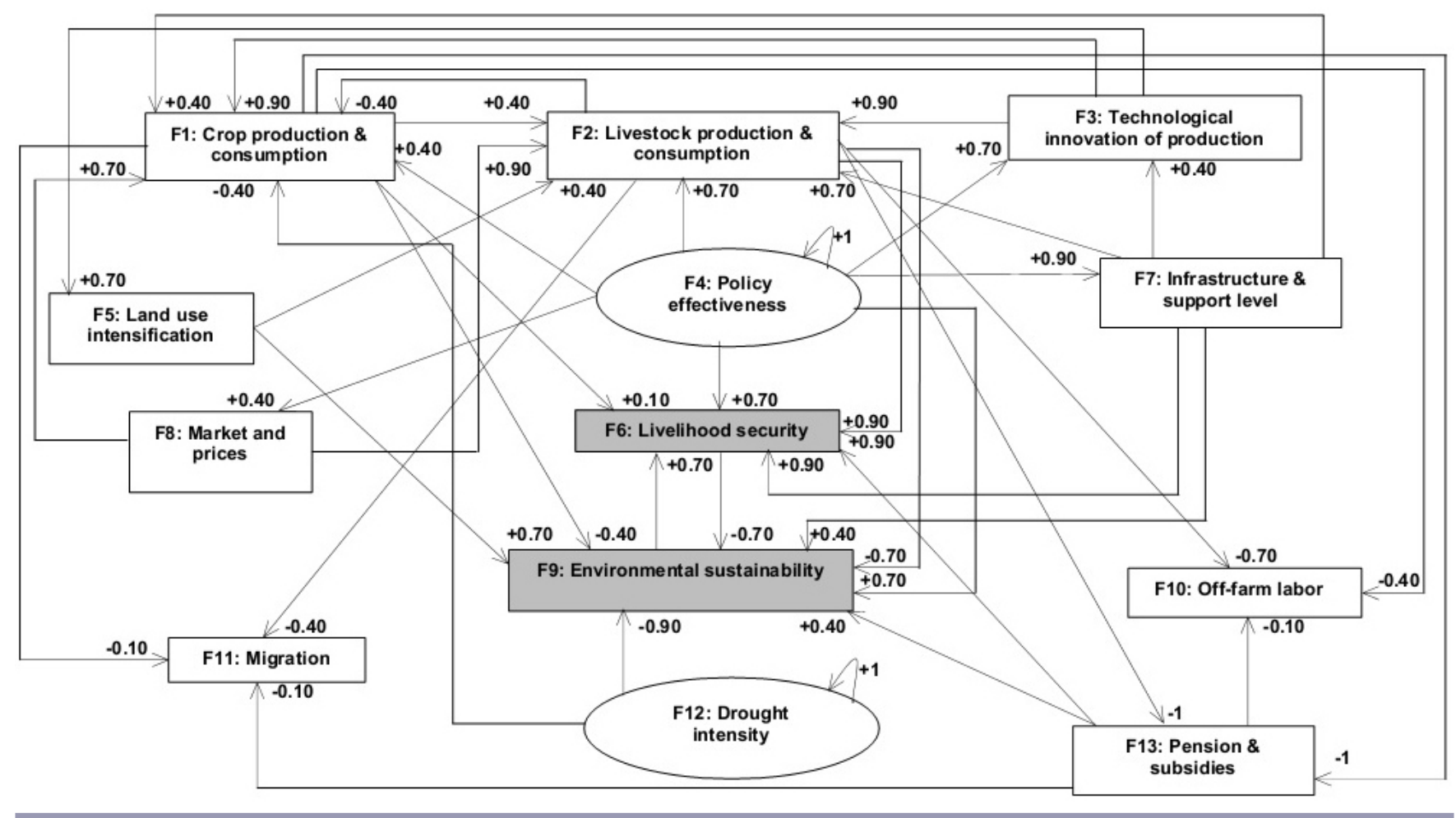

Table 5. Key characteristics of the maps.

\begin{tabular}{lccc}
\hline \hline Characteristics & Livestock & Diversified & Off-farm \\
\hline Number of factors (N) & 12 & 13 & 13 \\
Number of relationships (R) & 42 & 49 & 41 \\
Maximum of relationships & 132 & 156 & 156 \\
(MaxR) & & & \\
Density (C/MaxR) (D) & 0.32 & 0.31 & 0.26 \\
Positive relationships & 31 & 29 & 27 \\
Negative relationships & 11 & 20 & 14 \\
Number of receiving factors & 2 & 3 & 3 \\
Number of transmitting & 2 & 2 & 2 \\
factors & & & \\
\hline
\end{tabular}

Although most factors and key relationships are very similar for the three clusters (as can be seen visually in Fig. 4), there are also important differences. The main differences are not so much in the existence or absence of relationships, but rather in the weight a relationship is given. For instance, the causal relationship F1 (crop production and consumption) $\rightarrow$ F6 (livelihood security) was assigned a strength of +0.40 in the livestock cluster, +0.70 in the diversified cluster, and +0.10 in the off-farm cluster, expressing the importance of the former factor to the latter one for each cluster. The consequences of these different weightings are reflected in different system dynamics obtained by changing the vectors. These different dynamics are the main reason for keeping the three FCMs separate, despite their large similarities.
The number of incoming and outgoing relationships of a factor provides an indication of its importance. The more relationships, the more central a factor is in the system's description, and thus the more important it is in the farmers' perception. A large number of relationships in all FCMs relate mainly to policy effectiveness (F4), crop production and consumption (F1), and livestock production and consumption (F2). The assumed importance of the first factor relates to the fact that the small farmers are beneficiaries of the ARP, depending on its schemes to establish their farming enterprise. Additionally, policy effectiveness is a key driver, because it influences a number of other factors, but is not influenced by any factor. Therefore, it influences the system without being part of it. The other two factors relate to the small farmers' perceptions about ranching and farming, which are fundamental livelihood activities for most of them. Despite the low number of relationships, pensions and subsidies (F13) is also considered important because it has the most negative value in all FCMs and thus strongly influences the system. Therefore, these four factors together with the target factors, livelihood security and environmental sustainability (F6 and F9, respectively), are considered the most important factors in the system descriptions.

\section{Dynamics of the FCMs in terms of small farmers' current perceptions}

The current dynamics outputs for each livelihood cluster in relation to the four selected factors (F1, F2, F4, and F13), together with the target factors in the FCM analysis (F6 and F9), are presented in Figure 5. After stabilization, the graphs indicate the 
current dynamic situation of each factor, allowing a comparison among them.

Small farmers within the livestock and diversified clusters perceive that they are achieving livelihood security (orange line, highest positive). However, this is happening at the expense of environmental sustainability (green line, negative). Livestock activities are important to both groups of small farmers. The pension and subsidies factor is also negative for these clusters. Interestingly, small farmers in the off-farm cluster perceive livestock and crop production as important factors for them, but they are achieving neither livelihood security nor environmental sustainability (both negatives).

The key driver, policy effectiveness, is stable in all three clusters (Fig. 7). However, the results obtained from the sensitivity analysis show that the three FCMs are extremely sensitive to policy effectiveness. When the value of this factor in the change vector was changed from a positive $(0.1)$ to a negative value $(-0.1)$, for instance, final values of all factors in all FCMs changed in relative position to others and in final value, reinforcing its importance as key driver.

\section{Dynamics of the FCMs in terms of the SSPs scenarios}

The outputs of the FCMs can be presented in tabular or graphical form. We present these two options. Table 6 shows the final values of stabilization of the change vectors for all factors in the three FCMs, taking account of the current situation and the SSP scenarios. Figure 6 shows the outputs of the off-farm cluster represented graphically, taking account of the two scenarios.

The table (or graph) is interpreted by comparing the current situation and the SSP scenarios, observing the changes in position and degree of each factor. In the optimistic scenario (SSP1) of future changes in the livestock cluster, small farmers assure their livelihood security (13.2) from livestock (9.2) and crop production (5.9), while being independent from subsidies (-15.1). This result, compared with the chart of the current situation (Fig. 5), indicates that small farmers within the livestock cluster perceive that, in the sustainable scenario, livelihood security is enhanced by livestock and crop production. The outcome on environmental sustainability $(-1.3)$ is slightly attenuated compared with current situation (-1.5), although it is still negative. Pension and subsidies are less important because small farmers are achieving their livelihood from livestock and farming. In the pessimistic scenario (SSP3), crop and livestock production become negative (-2.9 and -4.6 , respectively), affecting livelihood security negatively (-6.6). In this scenario, small farmers depend largely on subsidies (7.6) to provide their livelihoods; however, environmental sustainability is positive (0.6), because of the fall in agricultural production.

In turn, in the optimistic scenario (SSP1) of future changes in the diversified cluster, small farmers assure their livelihood security (9.2) from livestock (5.0) and crop production (2.2), not depending on subsidies (-7.2). This scenario, however, is very negative for environmental sustainability (-7.6). Actually, reduced environmental sustainability is observed in SSP1 for two clusters and negative for all three. Surprisingly, reduced livelihood security for off-farm is also observed in SSP1. All in all, at the scale SSP1 is not perceived as having a positive impact on local dynamics. In turn, in the pessimistic scenario (SSP3), crop and livestock production become negative ( -1.2 and -2.8 , respectively), affecting
Fig. 7. Outputs of the three fuzzy cognitive maps. X-axis: number of iteration steps. After stabilization, each line indicates the current dynamic situation of each factor, according to the small farmers' current perceptions; Y-axis: value of factors. The values indicate whether the small farmers perceived positively or negatively each factor. Higher values indicate the importance of the factor.
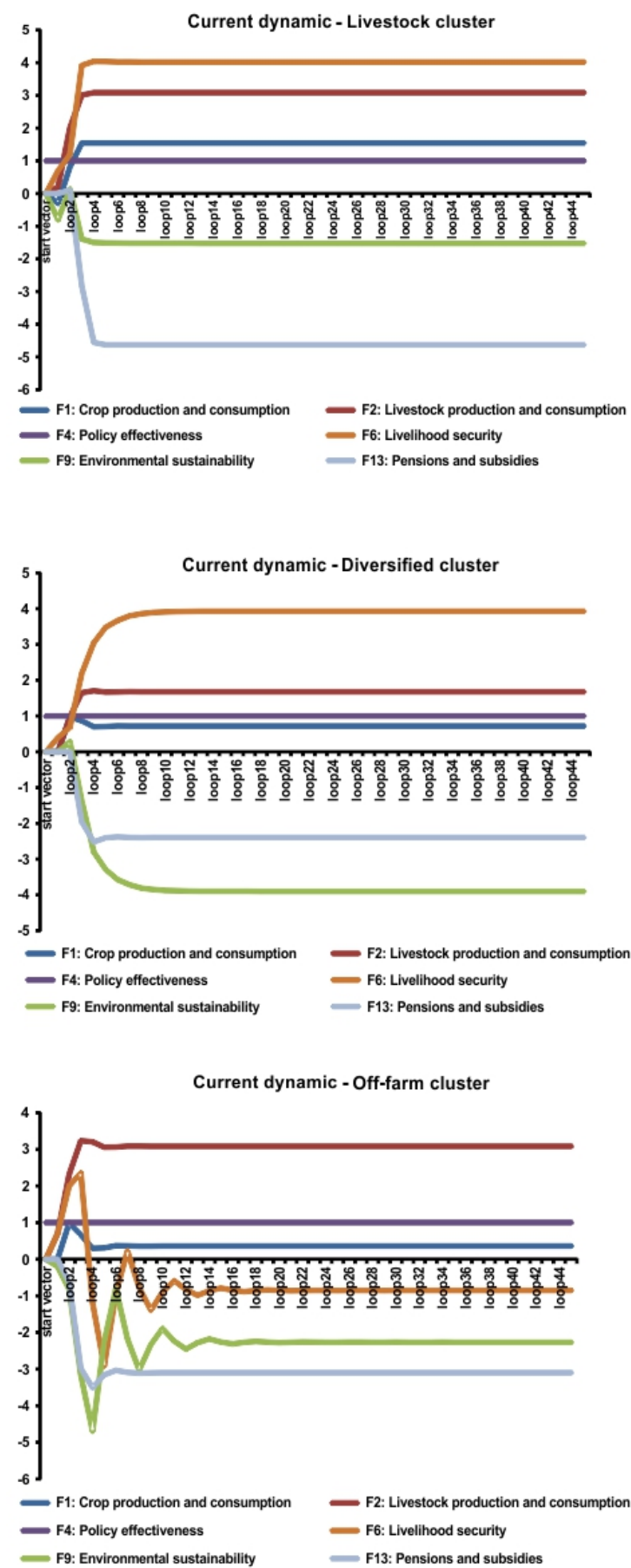
Table 6. Final values of stabilization of the change vectors for the factors in the three fuzzy cognitive maps.

\begin{tabular}{|c|c|c|c|c|c|c|c|c|c|}
\hline \multirow[t]{2}{*}{$\overline{\text { Factors }}$} & \multicolumn{3}{|c|}{ Livestock } & \multicolumn{3}{|c|}{ Diversified } & \multicolumn{3}{|c|}{ Off-farm } \\
\hline & $\begin{array}{l}\text { Current } \\
\text { situation }\end{array}$ & SSP1 & SSP3 & $\begin{array}{l}\text { Current } \\
\text { situation }\end{array}$ & SSP1 & SSP3 & $\begin{array}{l}\text { Current } \\
\text { situation }\end{array}$ & SSP1 & SSP3 \\
\hline $\begin{array}{l}\text { F1: Crop production and } \\
\text { consumption }\end{array}$ & 1.5 & 5.9 & -2.9 & 0.7 & 2.2 & -1.2 & 0.4 & 1.4 & -0.8 \\
\hline $\begin{array}{l}\text { F2: Livestock production and } \\
\text { consumption }\end{array}$ & 3.1 & 9.2 & -4.6 & 1.7 & 5.0 & -2.8 & 3.1 & 6.4 & -3.5 \\
\hline $\begin{array}{l}\text { F3: Technological innovation of } \\
\text { production }\end{array}$ & 1.7 & 3.3 & -1.7 & 0.20 & 0.40 & -0.20 & 1.1 & 2.1 & -1.2 \\
\hline F4: Policy effectiveness & 1.0 & 2.0 & -1.0 & 1.0 & 2.0 & -1.0 & 1.0 & 2.0 & -1.0 \\
\hline F5: Intensification of land use & .60 & 1.2 & -0.6 & 0.5 & 1.0 & -0.60 & 0.7 & 1.5 & -0.8 \\
\hline F6: Livelihood security & 4.0 & 13.2 & -6.6 & 3.9 & 9.2 & -4.7 & -0.3 & -1.1 & 0.9 \\
\hline $\begin{array}{l}\text { F7: Infrastructure and support } \\
\text { expansions }\end{array}$ & 0.4 & 0.8 & -0.4 & 0.7 & 1.4 & -0.80 & 0.9 & 1.8 & -1.0 \\
\hline F8: Market and prices & 0.7 & 1.4 & -0.7 & 0.3 & 0.60 & -0.30 & 0.4 & 0.8 & -0.4 \\
\hline F9: Environmental sustainability & -1.5 & -1.3 & 0.6 & -3.9 & -7.6 & 3.3 & -2.6 & -3.9 & 1.9 \\
\hline $\begin{array}{l}\text { F10: Reduction of off-farm } \\
\text { labor }\end{array}$ & 0.0 & 0.0 & 0.0 & -2.6 & -6.3 & 3.5 & -1.9 & -4.4 & 2.4 \\
\hline F11: Migration & -1.8 & -5.2 & 2.6 & -1.4 & -3.6 & 2.0 & -0.9 & -2.0 & 1.1 \\
\hline F12: Intensification of drought & 1.0 & -2.0 & 1.0 & 1.0 & -2.0 & 2.0 & 1.0 & 0.0 & 0.0 \\
\hline F13: Pensions and subsidies & -4.6 & -15.1 & 7.6 & -2.4 & -7.2 & 4.0 & -3.1 & -7.1 & 3.9 \\
\hline
\end{tabular}

The key factors and target factors are in bold.

livelihood security negatively (-4.7). In this scenario, small farmers depend on subsidies (4.0) to provide their livelihoods. On the other hand however, environmental sustainability has its best outcome (3.3), precisely because of the decrease in agricultural production and the increased abandonment of agricultural areas.

As a graphical interpretation of the FCMs outputs, Figure 6 shows the outcomes of the small farmers in the off-farm cluster. When the chart of the current situation (Fig. 5) is compared with the SSP scenarios (Fig. 6), it is clear that the dynamics of the factors change in position and degree.

In the optimistic scenario, small farmers in the off-farm cluster enhance livestock and crop production, but they are still not achieving livelihood security. Environmental sustainability also decreases in this scenario, despite this being a "sustainable" scenario. In the pessimistic scenario (SSP3), pensions and subsidies are the basis for livelihood security. Surprisingly, small farmers in this situation have positive livelihood security, but livestock and other agricultural production are negative. These factors affect environmental sustainability positively (Fig. 8).

\section{DISCUSSION}

Small farmers' current perceptions and scenarios: similarities and differences in the three FCMs

It was not unexpected that the FCMs constructed by the three livelihood strategy subgroups were very similar in terms of factors and relationships. The specific group of small farmers considered here are subject to the same set of ARP policies, they are in the same geographical region, and they all depend on livestock to some extent. So, small farmers with different livelihood strategies perceive the same factors as affecting their livelihood security and environmental sustainability. Small farmers in the livestock cluster did not consider reduction of off-farm labor (F10) as an important factor for them because, in general, livestock activities, mainly dairy cattle, are labor intensive (Vosti et al. 2003, Tourrand
Fig. 8. Output of the SSP1 scenario (sustainability) and of the SSP3 scenario (fragmentation) for the off-farm cluster. X-axis: number of iterations of vector matrix, indicating the number of loops necessary to the stabilization; Y-axis: value of the factors. Values indicate the importance of the factor in different scenarios.
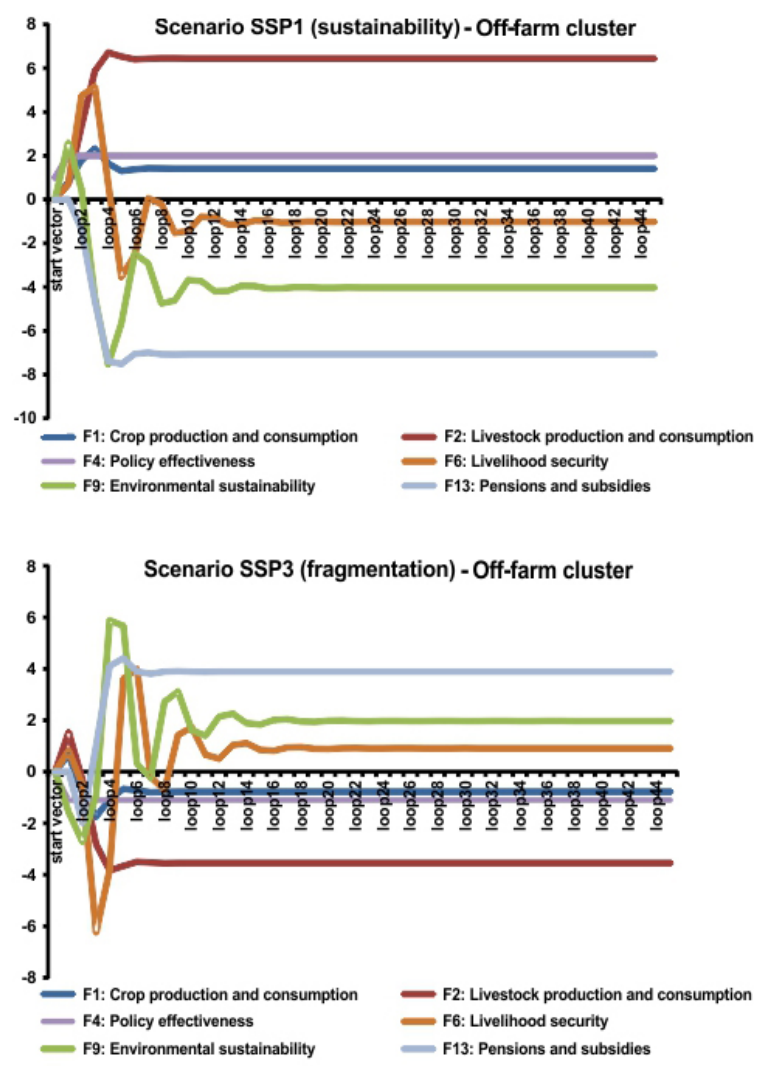
et al. 2004). However, some relationships and most weights between relationships are different among the three FCMs. In other words, the majority of small farmers agree on the same factors, and by and large also on the same cause and effect relationships. Nonetheless, relatively subtle differences in the weights attributed to these relationships have given rise to very different system behavior. This could indicate that the system perspective differs among the three livelihood strategies, depending on how small farmers perceive the interaction of factors in terms of relationships and the weight of each interaction.

Different perceptions of their realities resulted in the small farmers making different trade-offs between livelihood security and environmental sustainability, depending on their livelihood cluster. As pointed out by Sunderlin et al. (2005), many plans of action aim for win-win outcomes, where livelihood improvements are matched by gains in environmental protection. However, the results indicated win-lose outcomes in the livestock and diversified clusters, in terms of the current situation and of the sustainable scenario. This means that small farmers are achieving their livelihood security at the expense of environmental sustainability. This can be attributed to the necessity to keep the pasture areas cleared to assure livelihoods in the livestock cluster and to the fallow agriculture in the diversified cluster (Fujisaka et al. 1996, Vosti et al. 2003). The impact of crop production on environmental sustainability is minor because livestock production has a bigger role for the small farmers (Vosti et al. 2003). As suggested by Sunderlin et al. (2005), policy lessons should be guided by the analysis of this type of outcome in terms of two principal types of solutions. The first would involve reducing the trade-offs and, in essence, seeking outcomes of the type winning more and losing less. It could be associated with technological innovation and implementation of agro-ecological systems in the settlement projects (Altieri 2002, Monteiro Novo 2012). The second would involve identifying the appropriate point on the trade-off curve, for example, the optimal level of wellbeing, or the optimal level of forest cover, cognizant of the biophysical, economic, and political consequences of forest conversion (Kaimowitz et al. 1998, Sunderlin et al. 2005). We know from a previous study (Diniz et al. 2013a) that signs of forest transition appeared in the municipality and on some properties in the period from 2005 to 2010, showing the possibility of a winwin outcome between livelihood security and environmental sustainability in the livestock and diversified clusters. Consequently, policies such as the Ministry of Environment's "green grant" (bolsa-verde; MMA 2013) that maintain and expand secondary forest in the municipality are recommended.

The situation for small farmers in the off-farm cluster is even worse: the outcome is lose-lose in the current situation as well as in the sustainable scenario because they are achieving neither livelihood security nor environmental sustainability. Curiously, however, the unique situation of win-win outcomes is observed precisely in the pessimistic scenario for small farmers in the offfarm cluster: in this case, both livelihood security and environmental sustainability are achieved. This can be attributed to the farmers' dependence on the government to provide their livelihoods and the abandonment of agricultural areas in this scenario, respectively. Although achieving a win-win outcome, this situation cannot serve as an example to be reproduced, as suggested by Sunderlin et al. (2005); rather, this apparent win-win outcome could cause more social and environmental problems because the small farmers might migrate to the outskirts of the cities (or to favelas) or to a new forest frontier, causing more deforestation elsewhere. These results indicate that the fuzzy cognitive map produced counterintuitive but explainable results, something that other types of methods would most likely not have yielded.

To sum up, analysis of the livelihood strategies of subgroups of small farmers proved useful to uncover differences in perceptions about the system. The combination of livelihood strategies and system dynamics is powerful in gaining understanding of how various groups of small farmers perceive the system. Moreover, different trade-offs were observed, implying different necessities for actions and policies. Achieving win-win outcomes does not necessarily imply a positive scenario, especially if small farmers are dependent on income transfers from the government to provide their livelihood.

\section{Pros and cons of exploring system dynamics using FCMs}

Fuzzy cognitive mapping was designed to be applied to stakeholders with a relatively good understanding of system dynamics, usually those with a higher education level (van Vliet et al. 2010, Soler et al. 2012). In fact, local stakeholders, such as small farmers, were said to, in principle, often struggle with the concept of a system diagram. It was believed that they would have difficulty understanding the wider conceptual meanings, such as causes of deforestation, and their perceptions were often narrowed down to very localized factors (Wulms 2012). On the other hand, they are part of the system addressed in this paper, and therefore it is crucial to understand and analyze their perceptions (Chambers 1994, Schiere et al. 2004). Although the literature, generally, advises not to develop FCMs with local small farmers, we have shown that, under certain conditions, they do work. Specific reasons include first, that most local small farmers were in some way engaged in social movements in the land struggle, making them more aware of social and land issues, and this probably resulted in more active participation in the workshops. In addition, the prior mutual knowledge among participants and the facilitator of the workshops helped in getting a positive outcome. Because of the facilitator's previous knowledge about the small farmers and their livelihood strategies (Diniz et al. 2013b), it was possible to propose general factors at the beginning of the workshops. This facilitated a smooth process because the small farmers did not have very much time (or patience) to discuss all possible factors present in their context, despite their willingness to participate in the construction of the maps. However, we did not develop scenarios or even discuss future changes with the small farmers mostly because of their time availability. From the experiences of the three workshops discussed in this paper, it can be stated that organizing workshops with local stakeholders to develop FCMs quickly has proved possible. However, more research is needed to know the extent to which special circumstances made this experience an exception rather than a rule.

Although not a direct objective of this paper, it has been demonstrated that FCM can be an important tool in the process of exchanging information and coproducing knowledge, and thereby contributing toward social learning (Isak 2008). The main 
contributory factor is the fact that practical implicit knowledge has been structured and made more explicit. The learning process can be illustrated by a quote from a participant in the livestock workshop. When asked what he thought of the outcomes of the workshop, he said: "It is a map that is in our head for a long time, but we did not stop to think about it and organize it yet." Thus, the mapping exercise was positive in terms of both capturing the current perception of the system and social learning.

A further advantage of using fuzzy cognitive mapping as a method is the possibility of obtaining new insights into the behavior of livelihood systems, uncovering relationships between factors that would not be noticed using other methods alone, such as household surveys. Moreover, the method becomes stronger if used in combination with other methods, such as individual openended interviews, as we did. Thus, a mixed methods approach is more adequate to investigate mental models in the humanenvironment interaction, as also suggested by Lynam et al. (2012). Using FCMs to study the dynamics of a system can reveal differences that are hidden when only the factors of importance or the sensitivity of the system are taken into account. The dynamics of the system also reveal the heterogeneity of a group of stakeholders such as small farmers in agrarian settlement projects.

Despite its advantages, fuzzy cognitive mapping has drawbacks as well. In our case, the workshops were limited to a small number of participants because not all farmers participated in them. Moreover, only a limited number of factors can be included in the discussion. On the one hand, a strong focus on numbers might relegate discussions on less tangible issues to the background, and the semiquantitative character of the outcomes in the FCMs may limit their use as input in mathematical models. As highlighted by Kok (2009), in this case, semiquantification can be a blessing or a burden.

The necessity of a large amount of postprocessing can also be considered a drawback of the tool. Contrary to other participatory methods and tools, FCMs need postprocessing and reworking, thus increasing the role of the scientist. It would have been more appropriate to discuss the postprocessed versions of the FCMs with the participants again, as a validation process, obtaining more accurate maps. However, because of time and financial resources constraints, this was impossible. We therefore opted to provide a very detailed insight into all steps in the postprocessing stage, thus maximizing the transparency of the overall process.

In short, there are important advantages and disadvantages of using fuzzy cognitive mapping as a main participatory tool. This paper has, hopefully, shown that the advantages of structuring mental models and exploring dynamics outweigh the disadvantages of postprocessing and somewhat limited stakeholder participation.

\section{CONCLUSION}

Small farmers in the study area all have a similar perception of the factors that affect their livelihood security and environmental sustainability, independent of the livelihood strategy they adopt. All farmers perceive agricultural activities (livestock and crop production); policy effectiveness; and pensions and subsidies as being the most important factors. Nevertheless, opinions differed substantially on how factors related to each other, in terms of both the existence of relationships and of the weights attributed to the relationships. These often seemingly subtle differences, however, gave rise to fundamentally different system dynamics between livelihood strategies, importantly represented by clear differences in trade-offs between livelihood security and environmental sustainability. The scenario analysis showed how these trade-offs can change but generally become more pronounced in both futures explored. Hence, the goals of sustainable development seem not easy to realize in the area, given the characteristics and drivers of the human-environment systems, as identified by the settlers. In this way, achieving winwin outcomes does not necessarily imply a desirable scenario, as was indicated by the dependency of small farmers on income transfers from the government to provide their livelihood.

Although all findings within this study point toward a situation where either livelihoods or the environment benefit, but not both, there might be light at the end of the tunnel because previous work has demonstrated that there are signs of a forest transition in the municipality and in some settlement projects. Such transitions can be enhanced by policies such as the "green grant."

Despite potential disadvantages of using fuzzy cognitive mapping as a main participatory tool, it facilitates the description of the system as a whole, rather than merely listing factors. In this study, it helped to uncover differences between various livelihood strategies that would otherwise have remained hidden. It might be useful to support policies toward (more) win-win outcomes, acknowledging the fundamentally different dynamics of specific human-environmental contexts.

Responses to this article can be read online at: http://www.ecologyandsociety.org/issues/responses. $\mathrm{php} / 7286$

\section{Acknowledgments:}

The research presented in this article was supported by the IPOP Scaling and Governance program under the project (5110246-01) "Competing Claims on Natural Resources" and The Brazilian Agricultural Research Corporation (Embrapa). Generous support was also provided by the municipality of Eldorado do Carajás. This work would not be possible without the invaluable participation and friendship of the people of Água Fria, Canudos, Progresso, Moça Bonita, and Boca do Lago settlement projects and their respective organizations. We also thank Euclides Souza, Deuzinho Alves, Renata Araújo, and every settler and technician for their logistical and intellectual support during fieldwork.

\section{LITERATURE CITED}

Altieri, M. A. 2002. Agroecology: the science of natural resource management for poor farmers in marginal environments. Agriculture, Ecosystems \& Environment 93:1-24. http://dx.doi. org/10.1016/S0167-8809(02)00085-3

Betts, R. A., Y. Malhi, and J. T. Roberts. 2008. The future of the Amazon: new perspectives from climate, ecosystem and social 
sciences. Philosophical Transactions of the Royal Society B: Biological Sciences 363:1729-1735. http://dx.doi.org/10.1098/ rstb.2008.0011

Biggs, D., N. Abel, A. T. Knight, A. Leitch, A. Langston, and N. C. Ban. 2011. The implementation crisis in conservation planning: could "mental models" help? Conservation Letters 4:169-183. http://dx.doi.org/10.1111/j.1755-263X.2011.00170.x

Brondízio, E. 2005. Intraregional analysis of land use change in the Amazon. Pages 223-252 in E. F. Moran and E. Ostrom, editors. Seeing the forest and the trees: human-environment interactions in forest ecosystems. MIT Press, Cambridge, Massachusetts, USA.

Caviglia-Harris, J. L. 2004. Household production and forest clearing: the role of farming in the development of the Amazon. Environment and Development Economics 9:181-202. http://dx. doi.org/10.1017/S1355770X03001165

Chambers, R. 1994. The origins and practice of participatory rural appraisal. World Development 22:953-969. http://dx.doi. org/10.1016/0305-750X(94)90141-4

Chambers, R., and G. R. Conway. 1991. Sustainable rural livelihoods: practical concepts for the 21st century. Discussion Paper 296. Institute of Development Studies, University of Sussex, Brighton, UK.

Cheong, S.-M., D. G. Brown, K. Kok, and D. Lopez-Carr. 2012. Mixed methods in land change research: towards integration. Transactions of the Institute of British Geographers 37:8-12. http:// dx.doi.org/10.1111/j.1475-5661.2011.00482.x

Craik, K. J. W. 1967. The nature of explanation. Cambridge University Press, Cambridge, UK.

de Miranda, E. E., and C. Mattos. 1992. Brazilian rain-forest colonization and biodiversity. Agriculture Ecosystems \& Environment 40:275-296. http://dx.doi.org/10.1016/0167-8809 (92)90098-V

Diniz, F. H., M. A. Hoogstra-Klein, K. Kok, and B. Arts. $2013 b$. Livelihood strategies in settlement projects in the Brazilian Amazon: determining drivers and factors within the agrarian reform program. Journal of Rural Studies 32:196-207. http://dx. doi.org/10.1016/j.jrurstud.2013.06.005

Diniz, F. H., K. Kok, M. C. Hott, M. A. Hoogstra-Klein, and B. Arts. 2013a. From space and from the ground: determining forest dynamics in settlement projects in the Brazilian Amazon. International Forestry Review 15(4):442-455. http://dx.doi. org/10.1505/146554813809025658

Du Toit, D. R., H. Biggs, and S. Pollard. 2011. The potential role of mental model methodologies in multistakeholder negotiations: integrated water resources management in South Africa. Ecology and Society 16(3): 21. http://dx.doi.org/10.5751/ES-04237-160321

Ellis, F. 2000. The determinants of rural livelihood diversification in developing countries. Journal of Agricultural Economics 51:289-302. http://dx.doi.org/10.1111/j.1477-9552.2000.tb01229. $\underline{\mathrm{x}}$

EMBRAPA (Brazilian Agricultural Research Corporation) and INPE (National Institute for Space Research). 2011. TerraClass. Levantamento de informações de uso e cobertura da terra na
Amazônia. Sumário Executivo. EMBRAPA/INPE, Belém, Brazil. [online] URL: http://www.inpe.br/cra/projetos_pesquisas/ sumario executivo terraclass 2008.pdf

Faminow, M. D. 1997. Spatial economics of local demand for cattle products in Amazon development. Agriculture Ecosystems \& Environment 62:1-11. http://dx.doi.org/10.1016/S0167-8809 (96)01116-4

Fearnside, P. M. 2001. Land-tenure issues as factors in environmental destruction in Brazilian Amazonia: the case of southern Pará. World Development 29:1361-1372. http://dx.doi. org/10.1016/S0305-750X(01)00039-0

Fearnside, P. M. 2005. Deforestation in Brazilian Amazonia: history, rates, and consequences. Conservation Biology 19:680-688. http://dx.doi.org/10.1111/j.1523-1739.2005.00697.x

Fearnside, P. M. 2008. The roles and movements of actors in the deforestation of Brazilian Amazonia. Ecology and Society 13(1): 23. [online] URL: http://www.ecologyandsociety.org/vol13/iss1/ art23/

Fujisaka, S., W. Bell, N. Thomas, L. Hurtado, and E. Crawford. 1996. Slash-and-burn agriculture, conversion to pasture, and deforestation in two Brazilian Amazon colonies. Agriculture Ecosystems \& Environment 59:115-130. http://dx.doi. org/10.1016/0167-8809(96)01015-8

Godar, J., E. J. Tizado, and B. Pokorny. 2012. Who is responsible for deforestation in the Amazon? A spatially explicit analysis along the Transamazon Highway in Brazil. Forest Ecology and Management 267:58-73. http://dx.doi.org/10.1016/j.foreco.2011.11.046

Groumpos, P. 2010. Fuzzy cognitive maps: basic theories and their application to complex systems. Pages 1-22 in M. Glykas, editor. Fuzzy cognitive maps: advances in theory, methodologies, tools and applications. Springer, Berlin, Germany. http://dx.doi. org/10.1007/978-3-642-03220-2 1

Hecht, S. B. 1989. The sacred cow in the green hell: livestock and forest conversion in the Brazilian Amazon. Ecologist 19:229-234.

Hecht, S. B. 1993. The logic of livestock and deforestation in Amazonia: considering land markets, value of ancillaries, the larger macroeconomic context, and individual economic strategies . Bioscience 43:687-695. http://dx.doi.org/10.2307/1312340

Hecht, S. B. 2012. From eco-catastrophe to zero deforestation? Interdisciplinarities, politics, environmentalisms and reduced clearing in Amazonia. Environmental Conservation 39:4-19. http://dx.doi.org/10.1017/S0376892911000452

Humphries, S. S., and K. A. Kainer. 2006. Local perceptions of forest certification for community-based enterprises. Forest Ecology and Management 235:30-43. http://dx.doi.org/10.1016/j. foreco.2006.07.027

INPE (National Institute for Space Research). 2011. Projeto Prodes: Monitoramento da floresta Amazônica Brasileira por satélite. INPE, São José dos Campos, Brazil. [online] URL: $\underline{\text { http:// }}$ www.obt.inpe.br/prodes/index.php

INPE (National Institute for Space Research)/PRODES (Basin Restoration Program). 2012. Taxas anuais do desmatamento 1988 até 2012. INPE, São José dos Campos, Brazil. 
Instituto Nacioal de Colonização e Reforma Agrária (INCRA). 2012. Números da reforma agrária. INCRA, Brasília, Brasil. [online] URL: http://painel.incra.gov.br/sistemas/Painel/ ImprimirPainelAssentamentos.php?cod sr=27\&Parameters[Planilha] $=$ $\underline{\text { Nao\&Parameters[Box] }=\text { GERAL\&Parameters[Linha] }=1}$

Intergovernmental Panel on Climate Change (IPCC). 2012. Workshop report of the Intergovernmental Panel on Climate Change Workshop on socio-economic scenarios. O. Edenhofer, R. Pichs-Madruga, Y. Sokona, V. Barros, C. B. Field, T. Zwickel, S. Schloemer, K. Ebi, M. Mastrandrea, K. Mach, and C. von Stechow, editors. IPCC Working Group III Technical Support Unit, Potsdam Institute for Climate Impact Research, Potsdam Germany.

Isak, K. G. Q. 2008. Investigating fuzzy cognitive mapping as a participatory tool for conceptual landscape modelling. Københavns Universitet, Det Biovidenskabelige Fakultet for Fødevarer, Veterinærmedicin og Naturresourcer, Skov \& Landskab, Copenhagen, Denmark.

Jones, N. A., H. Ross, T. Lynam, P. Perez, and A. Leitch. 2011. Mental models: an interdisciplinary synthesis of theory and methods. Ecology and Society 16(1): 46. [online] URL: http:// www.ecologyandsociety.org/vol16/iss1/art46/

Kafetzis, A., N. McRoberts, and I. Mouratiadou. 2010. Using fuzzy cognitive maps to support the analysis of stakeholders' views of water resources use and water quality policy. Pages 383-402 in M. Glykas, editor. Fuzzy cognitive maps: advances in theory, methodologies, tools and applications. Springer, Berlin, Germany. http://dx.doi.org/10.1007/978-3-642-03220-2_16

Kaimowitz, D., N. Byron, and W. Sunderlin. 1998. Public policies to reduce inappropriate tropical deforestation. Pages 303-322 in E. Lutz, editor. Agriculture and the environment: perspectives on sustainable rural development. World Bank, Washington, D.C., USA.

Kirby, K. R., W. F. Laurance, A. K. Albernaz, G. Schroth, P. M. Fearnside, S. Bergen, E. M. Venticinque, and C. da Costa. 2006. The future of deforestation in the Brazilian Amazon. Futures 38:432-453. http://dx.doi.org/10.1016/j.futures.2005.07.011

Kok, K. 2009. The potential of fuzzy cognitive maps for semiquantitative scenario development, with an example from Brazil. Global Environmental Change 19:122-133. http://dx.doi. org/10.1016/j.gloenvcha.2008.08.003

Kosko, B. 1986. Fuzzy cognitive maps. International Journal of Man-Machine Studies 24:65-75. http://dx.doi.org/10.1016/ S0020-7373(86)80040-2

Langfield-Smith, K., and A. Wirth. 1992. Measuring differences between cognitive maps. Journal of the Operational Research Society 43:1135-1150. http://dx.doi.org/10.1057/jors.1992.180

Laurance, W. F., M. A. Cochrane, S. Bergen, P. M. Fearnside, P. Delamônica, C. Barber, S. D'Angelo, and T. Fernandes. 2001. The future of the Brazilian Amazon. Science 291:438-439. http://dx. doi.org/10.1126/science.291.5503.438

Line Carpentier, C., S. A. Vosti, and J. Witcover. 2000. Intensified production systems on western Brazilian Amazon settlement farms: could they save the forest? Agriculture, Ecosystems \&
Environment 82:73-88. http://dx.doi.org/10.1016/S0167-8809(00) $\underline{00217-6}$

Lynam, T., R. Mathevet, M. Etienne, S. Stone-Jovicich, A. Leitch, N. Jones, H. Ross, D. Du Toit, S. Pollard, H. Biggs, and P. Perez. 2012. Waypoints on a journey of discovery: mental models in human-environment interactions. Ecology and Society 17(3): 23. http://dx.doi.org/10.5751/ES-05118-170323

Malhi, Y., J. T. Roberts, R. A. Betts, T. J. Killeen, W. Li, and C. A. Nobre. 2008. Climate change, deforestation, and the fate of the Amazon. Science 319:169-172. http://dx.doi.org/10.1126/ science. 1146961

Marquette, C. M. 1998. Land use patterns among small farmer settlers in the Northeastern Ecuadorian Amazon. Human Ecology 26:573-598. http://dx.doi.org/10.1023/A:1018797325069

McCracken, S. D., B. Boucek, and E. F. Moran. 2002. Deforestation trajectories in a frontier region of the Brazilian Amazon. Pages 215-234 in S. J. Walsh and K. Crews-Meyer, editors. Linking people, place, and policy: a GIScience Approach. Kluwer Academic, Boston, Massachusetts, USA. http://dx.doi. org/10.1007/978-1-4615-0985-1_10

Ministério do Desenvovimento Agrário (MDA)/Instituto Nacioal de Colonização e Reforma Agrária (INCRA). 2004. II Plano Nacional de Reforma Agrária. MDA, Brasília, Brasil.

MMA (Ministry of Environment). 2013. Environmental Conservation Support Program - Bolsa Verde. MMA, Brasília, Brasil.

Monteiro Novo, A. L. 2012. Islands of dairy in a sea of sugarcane: the future of family dairy farming in Brazil. Proefschrift Wageningen University, Wageningen, the Netherlands.

Moore, G. T. 1979. Knowing about environmental knowing: the current state of theory and research on environmental cognition. Environment and Behavior 11:33-70. http://dx.doi. org/10.1177/0013916579111002

Moran, E. F. 1993. Deforestation and land use in the Brazilian Amazon. Human Ecology 21:1-21. http://dx.doi.org/10.1007/ $\underline{\mathrm{BF} 00890069}$

Moran, E. F., A. Siqueira, and E. Brondizio. 2003. Household demographic structure and its relationship to deforestation in the Amazon Basin. Pages 61-89 in J. Fox, R. R. Rindfuss, S. J. Walsh, and V. Mishra, editors. People and the environment: approaches for linking household and community surveys to remote sensing and GIS. Kluwer Academic, New York, New York, USA. http://dx. doi.org/10.1007/0-306-48130-8_ 3

Muchagata, M., and K. Brown. 2000. Colonist farmers' perceptions of fertility and the frontier environment in eastern Amazonia. Agriculture and Human Values 17:371-384. http://dx. doi.org/10.1023/A:1026531913099

Muchagata, M., and K. Brown. 2003. Cows, colonists and trees: rethinking cattle and environmental degradation in Brazilian Amazonia. Agricultural Systems 76:797-816. http://dx.doi. org/10.1016/S0308-521X(02)00015-X

Murungweni, C., M. T. van Wijk, J. A. Andersson, E. M. A. Smaling, and K. E. Giller. 2011. Application of fuzzy cognitive 
mapping in livelihood vulnerability analysis. Ecology and Society 16(4): 8. http://dx.doi.org/10.5751/ES-04393-160408

O’Neill, B. C., T. R. Carter, K. L. Ebi, J. Edmonds, S. Hallegatte, E. Kemp-Benedict, E. Kriegler, L. Mearns, R. Moss, K. Riahi, B. van Ruijven, and D. van Vuuren. 2012. Workshop on the nature and use of new socioeconomic pathways for climate change research: meeting report. National Center for Atmospheric Research, Boulder, Colorado, USA. [online] URL: https://www2.cgd.ucar. edu/sites/default/files/iconics/Boulder-Workshop-Report.pdf

Özesmi, U., and S. L. Özesmi. 2004. Ecological models based on people's knowledge: a multi-step fuzzy cognitive mapping approach. Ecological Modelling 176:43-64. http://dx.doi. org/10.1016/j.ecolmodel.2003.10.027

Pacheco, P. 2009. Smallholder livelihoods, wealth and deforestation in the eastern Amazon. Human Ecology 37:27-41. http://dx.doi.org/10.1007/s10745-009-9220-y

Papageorgiou, E. I. 2011. Review study on fuzzy cognitive maps and their applications during the last decade. Pages 828-835 in IEEE International Conference on Fuzzy Systems, Taipei, Taiwan. http://dx.doi.org/10.1109/FUZZY.2011.6007670

Posey, D. A. 1996. Indigenous knowledge, biodiversity, and international rights: learning about forests from the Kayapo Indians of the Brazilian Amazon. Commonwealth Forestry Review 76:53-60.

Rajaram, T., and A. Das. 2010. Modeling of interactions among sustainability components of an agro-ecosystem using local knowledge through cognitive mapping and fuzzy inference system. Expert Systems with Applications 37:1734-1744. http://dx. doi.org/10.1016/j.eswa.2009.07.035

Rosa, I. M. D., C. Souza, and R. M. Ewers. 2012. Changes in size of deforested patches in the Brazilian Amazon. Conservation Biology 26:932-937. http://dx.doi.org/10.1111/j.1523-1739.2012.01901. $\underline{\mathrm{X}}$

Salisbury, D. S., and M. Schmink. 2007. Cows versus rubber: changing livelihoods among Amazonian extractivists. Geoforum 38:1233-1249. http://dx.doi.org/10.1016/j.geoforum.2007.03.005

Schiere, J. B., R. Groenland, A. Vlug, and H. van Keulen. 2004. System thinking in agriculture: an overview. Pages 57-86 in $\mathrm{K}$. Rickert, editor. Emerging challenges for farming systems: lessons from Australian and Dutch agriculture. Rural Industries Research and Development Corporation, Barton, Australian Capital Territory, Australia.

Scoones, I. 1998. Sustainable rural livelihoods: a framework for analysis. Working Paper 72. Institute of Development Studies, University of Sussex, Brighton, UK.

Scouvart, M., R. T. Adams, M. Caldas, V. Dale, B. Mertens, V. Nedelec, P. Pacheco, B. Rihoux, and E. F. Lambin. 2008. Causes of deforestation in the Brazilian Amazon: a qualitative comparative analysis. Journal of Land Use Science 2:257-282. http://dx.doi.org/10.1080/17474230701785929

Shukla, J., C. Nobre, and P. Sellers. 1990. Amazon deforestation and climate change. Science 247:1322-1325. http://dx.doi. org/10.1126/science.247.4948.1322
Soares-Filho, B. S., D. C. Nepstad, L. M. Curran, G. C. Cerqueira, R. A. Garcia, C. A. Ramos, E. Voll, A. McDonald, P. Lefebvre, and P. Schlesinger. 2006. Modelling conservation in the Amazon basin. Nature 440:520-523. http://dx.doi.org/10.1038/nature04389

Soler, L. S., K. Kok, G. Camara, and A. Veldkamp. 2012. Using fuzzy cognitive maps to describe current system dynamics and develop land cover scenarios: a case study in the Brazilian Amazon. Journal of Land Use Science 7:149-175. http://dx.doi. org/10.1080/1747423X.2010.542495

Stone-Jovicich, S. S., T. Lynam, A. Leitch, and N. A. Jones. 2011. Using consensus analysis to assess mental models about water use and management in the Crocodile River Catchment, South Africa. Ecology and Society 16(1): 45. [online] URL: http://www. ecologyandsociety.org/voll6/iss1/art45/

Sunderlin, W. D., A. Angelsen, B. Belcher, P. Burgers, R. Nasi, L. Santoso, and S. Wunder. 2005. Livelihoods, forests, and conservation in developing countries: an overview. World Development 33:1383-1402. http://dx.doi.org/10.1016/j. worlddev.2004.10.004

Tourrand, J. F., J. B. d. Veiga, R. Poccard-Chapuis, N. Hostiou, L. A. Ferreira, R. M. R. Ludovino, and M. G. Piketty. 2004. The effects of cattle ranching on land use of family holdings in the eastern-Amazon region of Brazil. Pages 205-219 in D. Babin, editor. Beyond tropical deforestation: from tropical deforestation to forest cover dynamics and forest development. UNESCO/ CIRAD, Montpellier, France.

van Vliet, M., K. Kok, and T. Veldkamp. 2010. Linking stakeholders and modellers in scenario studies: the use of fuzzy cognitive maps as a communication and learning tool. Futures 42:1-14. http://dx.doi.org/10.1016/j.futures.2009.08.005

Vosti, S. A., J. Witcover, and C. L. Carpentier. 2003. Agricultural intensification by small-holders in the Western Brazilian Amazonfrom deforestation to sustainable land use. Research Report. International Food Policy Research Institute, Washington, D.C., USA.

Wulms, M. 2012. What drives deforestation? Linking the perception of local stakeholders with the interpretation of satellite images. Wageningen University, Wageningen, The Netherlands. 